\title{
ANALISIS PENGARUH RASIO KEUANGAN TERHADAP KONDISI FINANCIAL DISTRESS PERUSAHAAN MANUFAKTUR YANG TERDAFTAR DI BURSA EFEK INDONESIA
}

\author{
Taufik Hidayat ${ }^{1}$, Maulina Diyah Permatasari ${ }^{2}$, Tatang Suhamdeni ${ }^{3}$ \\ Universitas Pelita Bangsa \\ taufik.hidayat@pelitabangsa.ac.id
}

\begin{abstract}
ABSTRAK
Tujuan penelitian ini adalah (1) untuk menganalisis pengaruh rasio likuiditas terhadap kondisi financial distress perusahaan manufaktur yang terdaftar di BEI; (2) untuk menganalisis pengaruh rasio profitabilitas terhadap kondisi financial distress perusahaan manufaktur yang terdaftar di BEI; (3) untuk menganalisis pengaruh rasio leverage terhadap kondisi financial distress perusahaan manufaktur yang terdaftar di BEI; (4) untuk menganalisis pengaruh arus kas operasi terhadap kondisi financial distress perusahaan manufaktur yang terdaftar di BEI. Populasi yang digunakan di dalam penelitian ini adalah perusahaan manufaktur sub sektor makanan dan minuman yang terdaftar di Bursa Efek Indonesia tahun 2014-2018. Purposive sampling merupakan teknik pengambilan sampel dalam penelitian. Populasi penelitian sebanyak 26 perusahaan dengan jumlah sampel sebanyak 9 perusahaan dengan jumlah observasi data sebanyak 45 data. Metode analisis data yang digunakan adalah analisis regresi logistik. Hasil penilitian ini menunjukkan bahwa Rasio Likuiditas berpengaruh positif dan signifikan terhadap kondisi financial distress, sedangkan untuk Rasio Profitabilitas berpengaruh negatif dan signifikan terhadap kondisi financial distress, dan rasio leverage berpengaruh positif dan signifikan terhadap kondisi financial distress, sedangkan arus kas operasi tidak berpengaruh terhadap kondisi financial distress.
\end{abstract}

Kata Kunci: Financial Distress, Rasio Likuiditas, Rasio Profitabilitas, Rasio Leverage, dan Arus Kas Operasi

\section{ABSTRACT}

The objectives of this study are (1) to analyze the effect of the liquidity ratio on the financial distress of manufacturing companies listed on the IDX; (2) to analyze the effect of profitability ratios on financial distress conditions of manufacturing companies listed on the IDX; (3) to analyze the effect of the leverage ratio on the financial distress conditions of manufacturing companies listed on the IDX; (4) to analyze the effect of operating cash flows on the financial distress of manufacturing companies listed on the IDX. The population used in this study is the food and beverage sub-sector manufacturing companies listed on the Indonesia Stock Exchange in 2014-2018. The sampling technique used in this study was purposive sampling method. The study population was 26 companies with a total sample size of 9 companies with a total data observation of 45 data. The data analysis method used was logistic regression analysis. The results of this study indicate that the liquidity ratio has a positive and significant effect on financial distress, while the profitability ratio bas a negative and significant effect on financial distress, and the leverage ratio has a positive and significant effect on financial distress, while the operating cash flow have no effect on financial distress

Keywords: Financial Distress, Liquidity Ratio, Profitability Ratio, Leverage Ratio, and Operating Cash Flow

\section{PENDAHULUAN}

Kebangkrutan suatu perusahaan, terutama perusahaan besar akan membawa dampak negatif bagi manajemen, kreditor, investor, maupun pemerintah. Permasalahan tersebut menjadi 
hal yang diusahakan untuk dihindari, karena akibat yang ditimbulkan yaitu pernyataan pailit oleh pengadilan. Aturan mengenai kepailitan di Indonesia tercantum dalam UU No.1 tahun 1998, yang menyebutkan bahwa debitor yang mempunyai dua atau lebih kreditor dan tidak dapat membayar sedikitnya satu utang yang telah jatuh waktu dan tidak dapat ditagih, dinyatakan pailit dengan putusan pengadilan yang berwenang, baik atas permohonan sendiri, maupun atas permintaan lima orang atau lebih kreditornya. Kejaksaan dapat mengajukan permohonan kepailitan demi kepentingan umum.

Kepailitan ditandai dengan kondisi financial distress, kondisi tersebut ditandai dengan penurunan kondisi keuangan (Platt dan Platt, 2002). Tahap awal dimulai dari kesulitan likuiditas yang merupakan indikasi paling ringan sampai yang paling berat. Ketika arus kas perurahaan kurang dari jumlah utang jangka panjang yang telah jatuh tempo. Hal ini menandakan bahwa peusahaan tidak mampu melakukan pembayaran atas kewajiban yang dimilikinya (Whitaker, 1999). Perusahaan yang besar tidak terlepas dari permasalahan keuangan, besar kecilnya perusahana tidak dapat dijadikan patokan perusahaan tidak mengalami distress. Ketika perusahaan mengalami permasalahan keuangan, yang dirugikan bukan hanya pihak perusahaan, tetapi juga stakeholder dan shareholder terkena dampaknya.

Beberapa kategori penilaian financial distress (Elloumi dan Gueiye, 2001) mengkategorikan perusahaan mengalami financial distress jika perusahaan mempunyai Earning per Share (EPS) negatif. Pengukuran dengan menggunakan interest Coverage Ratio (ICR) (Wardhani, 2006). Dua pengukuran mengenai financial distress, pertama ketika perusahaan mengalami kerugian berturut-turut selama 2 tahun, kedua ketika perusahaan mengalami kerugian dan nilai buku ekuitasnya negatif selama 2 tahun berturut-turut (Almila, 2003). Perusahaan yang dikenai sanksikarna tidak memiliki solvabilitas yang baik dijadikan sebagai kategori pengukuran financial distress oleh Rahmat et al. (2009). Sedangkan Whitaker (1999) mengukur financial distress dari nilai arus kas yang lebih kecil dari pada utang jangka panjang saat ini.

Pengukuran financial distress dapat juga dilakukan dengan melakukan analisa laporan keuangan. Laporan keuangan merupkan bentuk dari hasil aktivitas bisnis dengan menggunakan metode, prosedur serta penjelasan-penjelasan dengan maksud untuk menmberikan informasi yang bermanfaat bagi para pengguna laporan keuangan. Kegunaan lain dari laporan keuangan selain memberikan informasi keuangan juga sebagai alat proyeksi keuangan di masa mendatang, juga untuk meramal kelangsungan hidup perusahaan yang berguna bagi manajemen dan pemilik perusahaan untuk melihat kemungkinan adanya kebangkrutan.

Penelitian awal yang mengkaji pemanfaatan analisis rasio keuangan untuk melakukan prediksi kebangkrutan perusahaan dilakukan oleh Altman (1968), model yang digunakan yaitu Altman yang dikenal sebagai Z-score. Sedangkan (Brigham \& Houston, 2010) menjelaskan bahwa rasio keuangan dalam mengantisipasi masa depan perusahaan. Selain itu Almilia dan Kristijasi (2003) menyatakan bahwa rasio keuangan dapat dijadikan sebagai alat untuk memprediksi kebangkrutan.

Rasio likuiditas merupakan salah satu rasio keuangan yang digunakan dalam memprediksi terjadinya financial distress. Kemampuan perusahaan dalam memenuhi kewajiban jangka pendeknya ditunjukkan oleh rasio likuiditas. Rasio lancar adalah salah satu penilaian dalam rasio likuiditas yang biasa digunakan untuk mengetahui kemampuan perusahaan dalam memenuhi kewajiban jangka pendeknya dengan menggunakan aktivitas lancar. Rasio ini menggambarkan kemempuan perusahaan dalam membayar kewajiban jangk apendeknya, semakinn tinggi rasio lancar maka semakin baik perusahaan dalam membayar kewajiban jangka pendeknya (Gamayuni, 2006).

Beberapa penelitian yang menunjukkan bahwa rasio lancar yang diproksikan melalui Current Ratio (CR) berpengaruh terhadap Financial Distress (FD) diantaranya, Almilia (2003) ynag menyatakan bahwa CR memiliki pengaruh negatif terhadap FD. Pengaruh negatif ini menunjukkan bahwa semakin tinggi nilai CR maka semakin kecil kemungkinan terjadinya FD. Namun berbeda dengan (Iramani, 2007), (Jiming \& Wei, 2011) yang menyatakan CR memiliki 
pengaruh positif dan signifikan sebagai prediktor terjadinya FD. Sedangkan (Widarjo \& Setiawan , 2009) dalam penelitiannya menunjukkan bahwa current ratio tidak berpengaruh terhadap kondisi financial distress perusahaan.

Rasio profitabilitas merupakan salah satu indikator yang digunakan untuk memprediksi terjadinya financial distress. Rasio profitabilitas adalah pengukuran kemampuan perusahaan pada dalam tingkat penjualan aset dan modal saham tertentu dalam menghasilkan laba bersih. Salah satu pengukuran profitabilitas adalah ROA (Return on Assets). ROA (Return on Assets) menunjukkan kemampuan perusahaan dengan menggunakan seluruh aktiva yang dimiliki untuk menghasilkan laba setelah pajak atau laba bersih operasi. Efektivitas manajemen aset dapat ditunjukkan melalui tingkat ROA yang tinggi. (Mamduh, 2009) "profitabilitas menggambarkan kemampuan perusahaan menghasilkan laba bersih berdasarkan tingkat aset tertentu". Dengan adanya efektivitas dari penggunaan aset perusahaan maka akan mengurangi biaya yang dikeluarkan oleh perusahaan, maka perusahaan akan memperoleh penghematan dan akan memiliki kecukupan dana untuk menjalankan usahanya. Dengan adanya kecukupan dana tersebut maka peluang perusahaan mengalami financial distress dimasa yang akan datang akan lebih kecil.

Faktor lain yang menjadi indikator atas prediksi kebangkrutan adalah rasio leverage. Rasio leverage merupakan kemampuan perusahaan dalam mengelola kewajiban yang dimilikinya. Terdapat dua macam leverage menurut (Etika, 2008) yaitu operating leverage dan financial leverage. Operating leverage menggunakan aset tertentu yang berdampak pada beban tetap bagi perusahaan, sedangkan financial leverage menggunakan sumber dan atertentu dari kewajiban perusahan yang berdampak pada beban tetap. Tergambar bahwa pengurangan aset perusahaan diakibatkan oleh leverage, jika peningkatan leverage sejalan dengan pemasukan perusahaan yang besar maka dapat mencegah terjadinya financial distress. (Almila \& Kristijadi, 2003) dan (Lie et al, 2008) membuktikan hubungan positif antara leverage dengan financial distress.

Arus kas merupakan campuran dari laporan laba rugi dan neraca (Subrayaman \& Wild, 2010), oleh karenanya dapat digunakan sebagai indikator financial distress. Laporan arus kas dapat mencerminkan nilai perusahaan melalui laba yang dihasilkan akibat dari arus kas yang meningkat. Arus kas terdiri dari tiga aktivitas, yaitu aktivitas operasi, aktivitas pendanaan dan aktivitas investasi. Dalam penelitian ini menggunakan arus kas aktivitas operasi, karena arus kas operasi merupakan indikator penentuan operasi perusahaan dalam menghasilkan kas. Jika arus kas operasi suatu perusahaan tinggi diartikan bahwa perusahaan memiliki sumber dana untuk melakukan aktivitas operasi tanpa mengandalkan pendanaan dari luar (Srengga, 2012)

\section{KAJIAN PUSTAKA \\ Financial Distress}

Kegunaan analisis laporan keuangan adalah untuk meramal kontinuitas atau kelangsungan hidup perusahaan. Prediksi kelangsungan hidup perusahaan sangat penting bagi manajemen dan pemilik perusahaan untuk mengetahui kondisi keuangan perusahaan dan mengantisipasi kondisi yang menyebabkan kemungkinan adanya potensi kebangkrutan. Financial distress atau sering disebut dengan kesulitan keuangan, ini terjadi sebelum suatu perusahaan benar-benar mengalami kebangkrutan. Menurut Plat dan Plat dalam (Fahmi, 2013) mendefinisikan financial distress sebagai tahap penurunan kondisi keuangan yang terjadi sebelum terjadinya kebangkrutan ataupun likuidasi.

Financial distress dimulai dengan tidak mempunyai kemampuan untuk memenuhi kewajiban-kewajibannya, terutama kewajiban yang bersifat jangka pendek termasuk kewajiban likuiditas, dan juga termasuk kewajiban kategori solvabilitas. Sedangkan menurut Beaver (2011) dalam (Rahmawati, 2015) financial distress didefinisikan sebagai ketidakmampuan perusahaan untuk membayar kewajiban financial yang telah jatuh tempo, financial distress terjadi karena ketidakmampuan perusahaan dalam membayar kewajibannya dikarenakan ketidakcukupan dana untuk melanjutkan usahanya. Ketika perusahaan mengalami penurunan dalam pertumbuhan laba dan aset tetap, serta adanya peningkatan persediaan relatif terhadap perusaaan yang sehat 
merupakan tanda umum perusahaan yang mengalami kesulitan keuangan (Kahya dan Theodossio,1999).

Financial distress juga ditandai dengan adanya penundaan pengirirman kualitas produk yang menurun dan penundaan pembayaran tagihan dari bank. Tindakan pencegahan dapat dilakukan melalui perbaikan dalam aset serta modal tertentu apabila kondisi financial distress ini diketahui. Sehingga perusahaan tidak masuk ke dalam tingkat kesulitan yang kebih berat seperti pailit atau likuidasi.Berdasarkan pengertian di atas dapat disimpulkan bahwa financial distress adalah kondisi perusahaan yang kesulitan keuangan karena tidak mampu memenuhi kewajiban-kewajibannya sebelum terjadinya kebangkrutan.

\section{Likuiditas}

Kemampuan suatu perusahaan dalam menyelesaikan semua kewajiban yang akan jatuh tempo melalui pencairan aset (Hani, 2015). Likuiditas mencerminkan ketersediaan dana yang dimiliki perusahaan dalam memenuhi semua hutang yang akan jatuh tempo. Likuiditas adalah pemenuhan kewajiban financial yang harus segera dilunasi (Riyanto, 2010). Likuiditas adalah rasio keuangan dalam memenuhi kewajiban jangka pendeknya, dengan menghubungkna jumlah kas dan aset lainnnya dnegan kewajiban jangka pendek, rasio yang umum digunakan yaitu current ratio dan quick ratio (Rambe, 2015). Berdasarkan pengertian di atas dapat disimpulkan bahwa likuiditas adalah kemampuan suatu perusahaan dalam memenuhi kewajiban untuk membayar utang-utang jangka pendek, yaitu utang usaha, utang dividen, utang pajak, dan lain-lain.

Tingkat likuiditas suatu perusahaan ditunjukkan dalam angka-angka tertentu, seperti : angka rasio cepat, angka rasio lancar, dan angka rasio kas. Tingkat likuiditas yang tinggi menunjukkan kinerja perusahaan yang semakin baik, maka perusahaan memiliki kesempatan kebih baik untuk mendapat dukungan dari berbagai pihak seperti lembaga keuangan, kreditur, maupun pemasok.

\section{Profitabilitas}

Kemampuan perusahaan dalam mendapatkan leuntungan atau laba selama satu periode tertentu dinamakan profitabilitas. Tingkat efektivitas manajemen dalam menghasilkan laba yang diperoleh dari penjualan atau pendapatan investasi ditunjukkan melalui rasio profitabilitas (Kasmir, 2015). Menurut (Sartono, 2010), menyatakan bahwa profitabilitas adalah kemampuan perusahaan dalam memperoleh laba yang hubungannya dengan penjualan total aktiva maupun modal sendiri. Sedangkan menurut (Hanafi, 2012), pengukuran kemampuan perusahaan dalam menghasilkan lana pada tingkat penjualan, aset, dan modal saham tertentu melalui pengukuran profit margin, return on asset (ROA) dan Return on Equity (ROE). Berdasarkan pengertian menurut para ahli di atas, maka dapat disimpulkan bahwa profitabilitas adalah kemampuan suatu perusahaan dalam menghasilkan laba selama periode tertentu pada tingkat penjualan, aset, dan modal saham tertentu. Profitabilitas suatu perusahaan dapat dinilai melalui berbagai cara tergantung pada laba dan aktiva atau modal yang akan diperbandingkan satu dengan yang lainnya.

\section{Leverage}

Leverage adalah rasio yang menggambarkan hubungan antara utang perusahaan terhadap modal, rasio ini dapat melihat seberapa jauh perusahaan dibiayai oleh utang atau pihak luar dengan kemampuan perusahaan yang digambarkan oleh modal (Harahap, 2013). Sedangkan menurut (Fahmi, 2012) leverage merupakan ukuran yang dipakai dalam menganalisis laporan keuangan untuk memperlihatkan besarnya jaminan yang tersedia untuk kreditor dan merupakan rasio yang mengukur seberapa besar perusahaan dibiayai oleh hutang. Secara luas (Kasmir, 2012) mengatakan bahwa rasio leverage digunakan untuk mengukur kemampuan perusahaan untuk membayar seluruh kewajibannya, baik jangka panjang maupun jangka pendek apabila perusahaan dilikuidasi. Berdasarkan pernyataan-pernyataan di atas, dapat disimpulkan bahwa leverage 
digunakan oleh suatu perusahaan bukan hanya untuk membiayai aktiva, modal serta menanggung beban tetap, melainkan juga untuk memperbesar penghasilan.

\section{Arus Kas Operasi}

Menurut Rudianto (2012:194), mendefinisikan arus kas sebagai suatu laporan tentang aktivitas penerimaan dan pengeluaran kas perusahaan selama periode tertentu, beserta penjelasan tentang sumber-sumber penerimaan dan pengeluaran kas tersebut. Arus kas operasi adalah aktivitas yang dilakukan perusahaan dalam memperoleh barang dan jasa, yang merupakan aktivitas rutin perusahaan seperti menjual barang (jasa), membeli barang (jasa), membayar bebanbeban operasi (gaji,sewa, asuransi, dll), pembayaran pajak, serta pembayaran bunga dari hutang. Perusahaan selalu mengharapkan arus kas dari aktivitas operasi adalah positif, yang berarti bahwa aktivitas rutin perusahaan lebih banyak menghasilkan kas dibandingkan dengan penggunaannya (Arief Sugiono, 2016:35).

\section{HIPOTESIS}

Hipotesis dalam karya ilmiah ini ditetapkan sebagai berikut :

1. Pengaruh Rasio Likuiditas terhadap Financial Distress Perusahaan Manufaktur Sub Sektor Food and Beverage yang Terdaftar di BEI (2014-2018)

Likuiditas menunjukkan kemampuan perusahaan dalam melunasi kewajiban lancarnya pada saat jatuh tempo. Tingginya tingkat likuiditas menunjukkan adanya jaminan atas dana kreditor yang berhubungan dengan operasional perusahaan seperti suplier akan semkain tinggi pula. Ketika tingkat likuiditas semakin baik, maka kemungkinan terjadinya financial distress semakin rendah. Ini sejalan dengan teori Brigham dan Houtson (2001), bahwa jika kewajiban lancar meningkat lebih cepat dibandingkan aktiva lancar maka rasio lancar akan turun dan ini bisa menimbulkan permasalahan, maka dapat dimungkinkan bahwa pola hubungan antara current ratio dengan probabilitas financial distress adalah negatif, artinya semakin tinggi current ratio maka semakin rendah tingkat financial distress suatu perusahaan.

Hasil penelitian terdahulu yang dilakukan oleh (Hapsari, 2012), dan (Murni, 2018) menunjukkan bahwa rasio likuiditas berpengaruh negatif dan signifikan terhadap kondisi financial distress.

\section{$\mathbf{H}_{1}$ : Rasio Likuiditas berpengaruh negatif dan signifikan terhadap kondisi financial distress}

2. Pengaruh Rasio Profitabilitas terhadap Kondisi Financial Distress Perusahaan Manufaktur Sub Sektor Food and Beverage yang Terdaftar di BEI (2014-2018)

Profitabilitas perusahaan menunjukkan hasil laba didapat dari tingkat efisiensi dan efektivitas penggunaan aset. Pada umumnya perusahaan aneka industri yang dijadikan sampel memiliki nilai profitabilitas negatif. Nilai negatif pada profitabilitas mengindikasikan bahwa tidak adanya efektivitas penggunaan aset perusahaan dalam menghasilkan laba. Salah satu perusahaan yang mengalami kondisi financial distress pada tahun 2006-2010 salah satunya adalah PT. Argo Pantes di mana perusahaan ini pada tahun 2006 memiliki profitabilitas sebesar $-0,91 \%$, pada tahun 2007 sebesar $-9,6 \%$, pada tahun 2008 sebesar $-10,93 \%$ dan pada tahun 2009 sebesar -5,18\%. Hasil Ini telah mengindikasikan adanya ketidakefektifan pengunaan aset dalam menghasilkan laba sehingga terdapat kemungkinan perusahana mengalami kondisi financial distress.

Hasil penelitian terdahulu yang dilakukan oleh (Orina Andre \& Salma Taqwa, 2014) menunjukkan bahwa profitabilitas berpengaruh negatif signifikan terhadap kondisi financial distress perusahaan.

$\mathbf{H}_{2}$ : Rasio Profitabilitas berpengaruh negatif dan signifikan terhadap kondisi financial distress 
3. Pengaruh Rasio Leverage terhadap Kondisi Financial Distress Perusahaan Manufaktur Sub Sektor Food and Beverage yang Terdaftar di BEI (2014-2018)

Kondisi financial distress yang dialami perusahaan umumnya memiliki jumlah yang hampir sama antara kewajiban dan asetnya. Kepemilikan jumlah utang perusahaan yang lebih besar dibandingkan dengan aset, pada umumnya memiliki nilai ejiutas negatif. Ketika hal itu terjadi kemungkinan perusahaan akan melakukan tindak pelanggaran dalam perjanjian utang dnegan kreditur, karena jumlah aset tidak mampu menjamin utang yang dimiliki perusahaan. Perusahaan yang memiliki utang tinggi juga akan dibebankan biaya bunga yang tinggi, leverage yang cukup tinggi telah mengindikasikan suatu kondisi financial distress yang dialami perusahaan. Maka dapat disimpulkan bahwa hubungan rasio leverage dengan financial distress adalah positif, yang artinya jika nilai leverage semakin besar maka kemunginan terjadinya financial distress akan semakin besar pula. Hasil penelitian terdahulu yang dilakukan oleh (Andre \& Taqwa, 2014) menunjukkan bahwa rasio leverage berpengaruh positif dan signifikan terhadap kondisi financial distress.

\section{$\mathbf{H}_{3}$ : Rasio Leverage berpengaruh positif dan signifikan terhadap kondisi financial distress}

4. Pengaruh Arus Kas Operasi terhadap Kondisi Financial Distress Perusahaan Manufaktur Sub Sektor Food and Beverage yang Terdaftar di BEI (2014-2018)

Laba bersih diekspresikan melalui laporan arus kas yang berkaitan dengan nilai perusahaan, sehingga jika terjadi peningkatan arus kas maka laba perusahaan akan meningkat dan hal ini akan meningkatkan nilai perusahaan dan selanjutnya juga akan menaikkan laba perusahaan. Arus kas operasi yang tinggi berarti perusahaan memiliki sumber dana untuk melakukan aktivitas operasinya seperti untuk melunasi pinjaman, memelihara kemampuan operasi perusahaan, membayar dividen, dan melakukan investasi baru tanpa mengandalkan sumber pendanaan dari luar. Dengan ini mengindikasikan bahwa hubungan antara arus kas operasi dengan kondisi financial distress perusahaan adalah negatif, yang artinya semakin tinggi nilai arus kas operasi maka kemungkinan perusahaan akan mengalami financial distress akan semakin kecil.

Hasil penelitian yang dilakukan oleh Imam Mas'ud dan Reva Maymi Srengga pada tahun 2012 menunjukkan bahwa arus kas operasi berpengaruh negatif dan signifikan terhadap kondisi financial distress.

\section{$\mathrm{H}_{4}$ : Arus Kas Operasi berpengaruh negatif dan signifikan terhadap kondisi financial distress}

\section{METODE PENELITIAN}

Jenis penelitian yang digunakan pada penelitian ini adalah penelitian kuantitatif untuk memperoleh bukti empiris dari prediksi kondisi financial distress menggunakan analisis rasio keuangan perusahaan. "Metode penelitian kuantitatif dapat diartikan sebagai metode penelitian yang berlandaskan pada filsafat positivisme, digunakan untuk meneliti pada populasi atau sampel tertentu, teknik pengambilan sampel pada umumnya dilakukan secara random, pengumpulan data menggunakan instrumen penelitian, analisis data bersifat kuantitatif dengan tujuan untuk menguji hipotesis yang telah ditetapkan" (Sugiyono, 2013).

Metode analisis data yang digunakan dalam penelitian ini adalah analisis regresi logistik, yang akan diolah dengan bantuan program SPSS. Analisis yang dapat digunakan untuk membuat model prediktif dari berbagai jenis data merupakan perangkat dasar dalam persamaan regresi. Regresi merupakan suatu metode dalam statistik yang dapat digunakan untuk melihat ada atau tidaknya hubungan (hubungan kasual atau sebab akibat) dan ditampilkan dalam bentuk model sistematis atau persamaan. Regresi logistik adalah sebuah pendekatan untuk membuat model prediksi seperti halnya regresi linier atau yang biasa disebut dengan istilah ordinary least square 
(OLS) regression, perbedaanya adalah pada regresi logistik, peneliti memprediksi variabel terikat yang berskala dikotomi. Skala dikotomi yang dimaksud adalah skala data nominal dengan dua kategori yaitu 0 dan 1.

Rumus model regresi logistik yang digunakan untuk menguji hipotesis adalah sebagai berikut:

Keterangan :

$$
\operatorname{Ln} \frac{p}{(1-p)}=\mathrm{a}+\mathrm{b} 1 \times 1+\mathrm{b} 2 \times 2+\mathrm{b} 3 \times 3+\mathrm{b} 6 x 4+\varepsilon
$$

$\operatorname{Ln} \frac{p}{(1-p)} \quad=$ status perusahaan

(Nilai $\mathrm{p}=0$, perusahaan yang non-financial distress; nilai $(1-\mathrm{p})=1$ perusahaan yang mengalamii financial distress

a

$\mathrm{b} 1 \mathrm{X} 1=$ Koefisien regresi dari likuiditas

b2 $=$ Koefisien regresi dari profitabilitas

b3 $=$ Koefisien regresi dari leverage

b4 $\quad=$ Koefisien regresi dari arus kas operasi

$\varepsilon \quad=$ Error

Populasi, sampel dan teknik pengambilan sampel

Seluruh data yang dijadikan sebagai perhatian kita dalam suatu ruang lingkup dan waktu yang ditentukan dinamakan populasi (Margono, 2010: 118). Sedangkan menurut (Sukmadinata, 2011) populasi adalah Lingkup penelitian yang dijadikan sebagai kelompok besar atau wilayah. Dari beberapa pendapat para ahli di atas, maka dapat disimpulkan bahwa populasi merupakan keseluruhan elemen, unit penelitian, unit analisis yang memiliki karakteristik tertentu yang dijadikan objek penelitian. Populasi data yang digunakan dalam penelitian ini adalah 26 perusahaan manufaktur sub sektor food and beverage yang terdaftar di Bursa Efek Indonesia (BEI) dari tahun 2014 sampai dengan tahun 2018. Data yang akan diolah adalah laporan keuangan tahunan periode 2014-2018 yang akan digunakan dalam menganalisis pengaruh rasio keuangan terhadap kondisi financial distress perusahaan.

Sampel adalah bagian dari jumlah dan karakteristik yang dimiliki oleh populasi (Sugiyono, 2011: 61). Sedangkan menurut Margono (2010: 121) sampel adalah sebagai bagian dari populasi. Berdasarkan beberapa pendapat di atas maka dapat disimpulkan bahwa sampel adalah sebagian dari populasi yang diambil. Teknik sampling sendiri menurut Sugiyono (2014: 116) merupakan teknik pengambilan sampel untuk menentukan sampel yang akan digunakan dalam penelitian. Metode pengambilan sampel yang akan digunakan dalam penelitian ini adalah metode Purposive Sampling, yaitu populasi yang akan dijadikan sampel penelitian adalah yang memenuhi kriteria sampel tertentu sesuai dengan yang dikehendaki peneliti dan kemudian dipilih berdasarkan pertimbangan tertentu disesuaikan dengan tujuan penelitian (Sugiyono, 2012: 117). Adapun yang menjadi kriteria penentuan sampel adalah sebagai berikut :

a. Perusahaan manufaktur sub sektor food and beverage yang terdaftar di Bursa Efek Indonesia.

b. Perusahaan manufaktur sub sektor food and beverage yang terdaftar di Bursa Efek Indonesia secara berturut-turut dari tahun 2014 sampai dengan tahun 2018.

c. Perusahaan manufaktur sub sektor food and beverage yang mempunyai nilai kapitalisasi di bawah Rp 10.000.000.000.000,00 (middle cap dan small cap) pada tahun 2018 (nilai saham $\mathrm{x}$ jumlah saham yang beredar).

d. Perusahaan manufaktur sub sektor food and beverage yang tidak melakukan merger dan akuisisi.

Perusahaan yang menjadi sampel dalam penelitian ini adalah perusahaan manufaktur sub sektor food and beverage yang terdaftar di Bursa Efek Indonesia, yang memenuhi kriteria pengambilan sampel dengan metode purposive sampling sebanyak 9 perusahaan. 
HASIL DAN PEMBAHASAN

Hasil Analisis dan Uji Hipotesis

Statistik Deskriptif

Teknik dokumentasi digunakan dalam pengumpulan data yang diperlukan. Sebelum dilakukan analisis untuk pengujian hipotesis, dijelaskan atau dideskripsikan data informasi mengenai pengaruh Likuiditas (Current Ratio), Profitabilitas (Return On Asset), Leverage (Debt Ratio), dan Arus Kas Operasi terhadap financial distress yang dilihat dari nilai minimum, nilai maksimum, nilai rata-rata (mean), dan standar deviasi pada tabel berikut ini:

\section{Tabel 1}

Tabel Statistik Deskriptif

\begin{tabular}{|c|c|c|c|c|c|}
\hline \multicolumn{6}{|c|}{ Descriptive Statistic } \\
\hline & $\mathrm{N}$ & Minimum & Maximum & Mean & Std. Deviation \\
\hline CR & 45 & .152 & 8.638 & 2.266 & 1.846 \\
\hline $\mathrm{ROA}$ & 45 & -.098 & .290 & .052 & .081 \\
\hline DR & 45 & .146 & 2.900 & .561 & .508 \\
\hline Arus Kas Operasi & 45 & -3.250 & 3.300 & 2.085 & 2.483 \\
\hline FD & 45 & 0 & 1 & .33 & .477 \\
\hline
\end{tabular}

Sumber: Output SPSS, data sekunder diolah 2020

Dari hasil uji statistik deskriptif didapatkan informasi sebagai berikut:

1. Nilai dari Current Ratio (CR), memiliki nilai minimum 0,152 dan maksimum 8,638 dengan ratarata sebesar 2,266 dan standar devuasi 1,846. Dengan sampel sebanyak 45 dan nilai rat-rata CR 1,846 menunjukkan bahwa tingkat likuiditas dinilai cukup baik yang berarti bahwa perusahaan mampu menutupi utang lancarnya dnegan menggunakan set lancar yang dimiliki.

2. Hasil uji statistik deskriptif dari Return On Asset (ROA) dengan jumlah $\mathrm{N}$ atau seluruh unit observasi penelitian sejumlah 45 unit data, memiliki nilai minimum yaitu -0,098. Nilai maksimum sebesar 0,290, artinya kemampuan maksimum perusahaan dalam menghasilkan laba bersih setelah pajak yaitu sebesar 29\% dari total aktivanya. Nilai rata-rata sebesar 0,052, ini menandakan bahwa rata-rata perusahaan dapat menghasilkan laba bersih setelah pajak sebesar 5\% dari total aktiva. Dan nilai standar deviasinya adalah sebesar 0,081.

3. Nilai minimum Debt Ratio (DR) yaitu 0,146, berarti bahwa kemampuan minimum perusahaan dalam menghasilkan laba bersih setelah pajak adalah sebesar $14 \%$ dari total aset. Nilai maksimum sebesar 2,900, artinya kemampuan maksimum perusahaan dalam menutupi hutangnya dengan menggunakan aset sebesar 290\%. Dan Nilai standar deviasinya sebesar 0,508, sedangkan dengan nilai rata-rata sebesar 0,561 menunjukkan bahwa sebesar 56\% dari harta yang dimiliki perusahaan untuk kegiatan operasionalnya di suply oleh kreditur dalam bentuk pinjaman dana.

4. Arus kas operasi memiliki nilai minimum sebesar -3.250. Nilai maksimum sebesar 3.300. Nilai rata-rata sebesar 2.085 dan nilai standar deviasinya sebesar 2.483. Nilai rata-rata aruskas operasi bernilai positif menandakann bahwa perusahaan memiliki kemampuan dalam mengelola arus kas operasinya.

5. Dengan menggunakan variabel dummy (0 dan 1), maka nilai rata-rata financial distress sebesar 0,33 . Dan nilai standar deviasinya sebesar 0,477 .

Standar deviasi untuk profitabilitas (ROA) dan Arus Kas Operasi yang lebih besar dari rata-rata menunjukkan bahwa data yang digunakan dalam variabel tersebut mempunyai sebaran besar, karena standar deviasi lebih besar dari rata-ratanya, sehingga simpangan data pada ketiga variabel tersebut dapat dikatakan tidak baik yang mengakibatkan standar deviasi untuk financial distress lebih besar dari rata-ratanya juga, hal ini menunjukkan bahwa data pada variabel profitabilitas (ROA) dan Arus Kas Operasi dalam penelitian ini terdapat beberapa outlier (data yang terlalu ekstrim). 


\section{Uji Asumsi Klasik}

Uji asumsi klasik bertujuan untuk mengetahui apakah hasil estimasi regresi yang dilakukan benar-benar bebas dari adanya gejala yang dapat mengganggu ketepatan analisis. Dalam penelitian ini uji asumsi klasik yang digunakan hanya uji multikolinearitas, karena variabel terikat yang digunakan adalah variabel dummy atau dikotomi (0 dan 1), sehingga residualnya tidak memerlukan pengujian asumsi klasik yang lain seperti uji normalitas, heteroksidasitas dan autokorelasi.

\section{Uji Multikolinearitas}

Uji multikolinearitas dalam penelitian ini dapat dilihat dari nilai Tolerance dan Variance Inflation Factor (VIF). Variabel bebas dikatakan mengalami multikolinearitas jika nilai tolerance < 0,10 dan VIF $>10$ atau variabel bebas tidak mengalami multikolinearitas jika nilai tolerance $>0,10$ dan VIF $<10$. Berikut hasil uji multikolinearitas yang diolah dengan SPSS versi 26:

Tabel 2

\section{Hasil Uji Multikolinearitas}

\begin{tabular}{|c|c|c|c|c|c|c|c|}
\hline \multirow[t]{2}{*}{ Model } & \multicolumn{2}{|c|}{$\begin{array}{c}\text { Unstandardized } \\
\text { Coefficients }\end{array}$} & \multirow{2}{*}{$\begin{array}{c}\text { Standardized } \\
\text { Coefficients } \\
\text { Beta }\end{array}$} & \multirow[t]{2}{*}{$\mathrm{T}$} & \multirow[t]{2}{*}{ Sig. } & \multicolumn{2}{|c|}{$\begin{array}{l}\text { Collinearity } \\
\text { Statistics }\end{array}$} \\
\hline & $\mathrm{B}$ & $\begin{array}{l}\text { Std. } \\
\text { Error }\end{array}$ & & & & Tolerance & VIF \\
\hline (Constant) & .329 & .135 & & 2.429 & .020 & & \\
\hline CR & .069 & .043 & .266 & 1.583 & .121 & .496 & 2.017 \\
\hline ROA & -4.311 & 1.095 & -.736 & -3.938 & .000 & .401 & 2.493 \\
\hline DR & .139 & .133 & .148 & 1.047 & .302 & .700 & 1.429 \\
\hline Arus Kas Operasi & -.002 & .024 & -.009 & -.068 & .946 & .868 & 1.152 \\
\hline
\end{tabular}

Sumber: Output SPSS, data sekunder diolah 2020

Berdasarkan tabel 2 di atas menunjukkan bahwa nilai tolerance dari Current Ratio (rasio likuiditas) sebesar 0,496, Return On Asset (rasio profitabilitas) sebesar 0,401, Debt Ratio (rasio leverage) sebesar 0,700, dan Arus Kas Operasi sebesar 0,868. Nilai-nilai tolerance dari variabel tersebut tersebut menunjukkan bahwa nilai tolerance dari masing-masing variabel lebih besar dari 0,10. Sedangkan nilai VIF dari variabel rasio likuiditas (Current Ratio) sebesar 2,017, variabel rasio profitabilitas (Return On Asset) sebesar 2,493, variabel rasio leverage (Debt Ratio) sebesar 1,429, dan variabel arus kas operasi sebesar 1,152, dimana masing-masing variabel memiliki nilai VIF lebih kecil dari 10. Nilai tolerance yang lebih besar dari 0,10 dan nilai VIF yang lebih kecil dari 10 menunjukkan bahwa model regresi tersebut bebas dari multikolinearitas dan baik untuk digunakan dalam penelitian, karena tidak terjadi korelasi diantara variabel independen.

\section{Analisis Regresi Logistik}

Analisis regresi logistik yaitu analisis yang digunakan dengan memprediksi variabel terikat yang bersifat dikotomi. Skala dikotomi berupa kategori; biasanya 0 dan 1 . Variabel terikat dalam penelitian ini adalah financial distress, dengan variabel bebas yaitu rasio likuiditas yang diproyeksikan dengan menggunakan current ratio (CR), rasio profitabilitas yang diproyeksikan dengan menggunakan return on asset (ROA), rasio leverage yang diproyeksikan dengan menggunakan debt ratio (DR), dan arus kas operasi yang diproyeksikan dengan menggunakan arus kas bersih. Berikut ini adalah hasil pengujian regresi logistik, yang diolah dengan menggunakan program aplikasi SPSS Versi 26:

\section{Tabel 3}

Hasil Uji Regresi Logistik 


\begin{tabular}{llrrrrrr}
\hline & & \multicolumn{1}{c}{ B } & \multicolumn{1}{c}{ S.E. } & Wald & Df & Sig. & Exp(B) \\
\hline Step 1 & CR & 3.267 & 1.591 & 4.219 & 1 & .040 & 26.240 \\
& ROA & -77.956 & 30.812 & 6.401 & 1 & .011 & .000 \\
& DR & 31.026 & 15.004 & 4.276 & 1 & .039 & 2.981 \\
& Arus Kas Operasi & .222 & .278 & .640 & 1 & .424 & 1.249 \\
& Constant & -20.180 & 9.842 & 4.204 & 1 & .040 & .000 \\
\hline
\end{tabular}

Sumber: Output SPSS, data diolah 2020

berikut:

Berdasarkan tabel 4.3 di atas diperoleh persamaan hasil pengujian regresi logistik sebagai

$$
\mathrm{FD}=-20,180+3,267 \mathrm{CR}-77,956 \mathrm{ROA}+31,026 \mathrm{DR}+\text { 0,222 Arus Kas Operasi }
$$

1. Konstanta (a) Financial Distress

Nilai konstanta sebesar -20,180 menunjukkan nilai negatif yang dapat dijelaskan bahwa tanpa adanya pengaruh dari variabel bebas yang digunakan dalam penelitian ini maka probabilitas financial distress akan menurun sebesar 20,180.

2. Koefisien Regresi (b1) Current Ratio

Variabel current ratio (Rasio Likuiditas) memiliki koefisien regresi positif sebesar 3,267. Artinya, jika variabel likuiditas meningkat sebesar satu satuan maka probabilitas perusahaan mengalami financial distress akan meningkat sebesar 3,267.

3. Koefisien Regresi (b2) Return on Asset

Variabel return on asset (Rasio Profitabilitas) memiliki koefisien regresi negatif sebesar -77,956. Hal ini berarti bahwa jika variabel profitabilitas meningkat sebesar satu satuan maka probabilitas perusahaan mengalami financial distress akan menurun sebesar 77,956.

4. Koefisien Regresi (b3) Debt Ratio

Variabel debt ratio (Rasio Leverage) memiliki koefisien regresi positif sebesar 31,026. Artinya, jika variabel leverage meningkat sebesar satu satuan maka probabilitas perusahaan mengalami financial distress akan meningkat sebesar 31,026.

5. Koefisien Regresi (b4) Arus Kas Operasi

Variabel arus kas operasi memiliki koefisien regresi positif sebesar 0,222. Artinya, jika variabel arus kas operasi meningkat satu satuan maka probabilitas perusahaan mengalami financial distress akan meningkat sebesar 0,222.

Uji kelayakan model regresi

1. Overall Fit Model

Penilaian keseluruhan model regresi menggunakan nilai -2 Log Likelihood di mana jika terjadi penurunan pada nilai -2 Log Likelihood pada balok kedua dibandingkan dengan blok pertama maka dapat disimpulkan bahwa model kedua dari regresi menjadi lebih baik. Berikut adalah hasil penelitian overall fit model pada nilai -2 Log Likelihood blok pertama yang hanya memasukkan konstanta saja:

\section{Tabel 4}

Blok Pertama (0)

\begin{tabular}{cccc}
\hline \multirow{2}{*}{ Iteration } & & $\begin{array}{c}-2 \text { Log } \\
\text { Likelihood }\end{array}$ & Coefficient \\
\cline { 3 - 4 } Step 0 & 1 & 57,293 & Constant \\
& 2 & 57,286 & $-0,667$ \\
& 3 & 57,286 & $-0,693$ \\
& &
\end{tabular}

Sumber: Output SPSS, data diolah 2020

Berdasarkan tabel 4 terlihat bahwa pada blok pertama, hanya dengan memasukkan konstanta saja nilai -2 Log Likelihood yang muncul adalah sebesar 57,286.

\section{Tabel 5}




\begin{tabular}{|c|c|c|c|c|c|c|c|}
\hline \multicolumn{8}{|c|}{ Blok Kedua (1) } \\
\hline \multicolumn{2}{|c|}{ Iteration } & \multirow{2}{*}{$\begin{array}{c}-2 \log \\
\text { likelihood }\end{array}$} & \multicolumn{5}{|c|}{ Coefficients } \\
\hline & & & Constant & $\mathrm{CR}$ & ROA & DR & $\begin{array}{c}\text { Arus Kas } \\
\text { Operasi }\end{array}$ \\
\hline Step & 1 & 35.868 & -.684 & .275 & -17.244 & .556 & -.007 \\
\hline \multirow[t]{9}{*}{1} & 2 & 29.502 & -1.205 & .498 & -31.081 & 1.199 & .021 \\
\hline & 3 & 24.773 & -3.715 & .817 & -39.382 & 5.390 & .041 \\
\hline & 4 & 20.120 & -10.215 & 1.718 & -49.338 & 15.709 & .078 \\
\hline & 5 & 18.718 & -15.426 & 2.537 & -64.040 & 23.741 & .141 \\
\hline & 6 & 18.428 & -18.966 & 3.084 & -74.441 & 29.171 & .200 \\
\hline & 7 & 18.411 & -20.097 & 3.255 & -77.720 & 30.900 & .221 \\
\hline & 8 & 18.411 & -20.179 & 3.267 & -77.955 & 31.025 & .222 \\
\hline & 9 & 18.411 & -20.180 & 3.267 & -77.956 & 31.026 & .222 \\
\hline & 10 & 18.411 & -20.180 & 3.267 & -77.956 & 31.026 & .222 \\
\hline
\end{tabular}

Sumber: Output SPSS, data diolah 2020

Setelah itu pada blok kedua yang disajikan dalam tabel 4.5 dengan memasukkan konstanta dan variabel bebasnya menghasilkan nilai 18,411 . Hasil pengujian keseluruhan overall fit model diketahui bahwa nilai -2 Log Likelihood blok kedua (block number $=1$ ) sebesar 18,411 lebih rendah daripada nilai 57,286 yang merupakan nilai -2 Log Likelihood blok pertama (block number $=0$ ). Sehingga, dibandingkan dengan blok pertama maka model kedua dari regresi adalah lebih baik.

\section{Nilai Goodness of Test}

Penggunaan Nilai goodness of test dalam rangka menguji kelayakan model regresi dalam memprediksi financial distress. Nilai Chi Square Hosmer and Lemeshow merupakan penilaian kelayakan model. Model fit dapat juga diuji dengan Hosmer Lemeshow Goodness of Fit yang menguji hipotesis nol bahwa data empiris cocok atau sesuai dengan model. Jika nilai Hosmer and Lemeshow signifikan atau lebih kecil dari 0,05 maka hipotesis ditolak dan model dikataan tidak fit, sebaliknya jika tidak signifikan maka hipotesis nol tidak dapat ditolak yang berarti data empiris sama dengan model atau model dikatakan fit (Ghozali, 2011). Berikut adalah output hasil uji Chi-square Hosmer and Lemeshow:

\section{Tabel 6}

Chi-Square Hosmer and Lemeshow

\begin{tabular}{|c|c|c|c|}
\hline Step & Chi-square & Df & Sig. \\
\hline 1 & 4,117 & 7 & 0,766 \\
\hline
\end{tabular}

Berdasarkan tabel 6 menunjukkan nilai Goodness of Fit Test yang diukur dengan nilai Chi-Square menunjukkan angka 4,117 dengan tingkat signifikansi sebesar 0,766. Berdasarkan teori yang dikemukakan (Ghozali, 2011), maka hasil dari uji ini menyimpulkan bahwa model regresi menjadi layak dipakai untuk analisis selanjutnya. Layak dipakai dalam penelitian bermaksud bahwa antara model dengan nilai observasinya tidak ditemui perbedaan yang nyata, sehingga model dapat dikatakan fit dengan data atau model dapat diterima.

3. Analisis Koefisien Determinasi

Koefisien determinasi dalam penelitian ini digunakan untuk mengetahui seberapa besar variabel-variabel independen yang digunakan yaitu rasio likuiditas yang diproyeksikan dengan current ratio, rasio profitabilitas yang diproyeksikan dengan return on asset, rasio leverage yang diproyeksikan dengan debt ratio, dan arus kas operasi mampu memperjelas variabilitas dari variabel dependen. Hasil koefisien determinasi pada regresi logistik dapat dilihat pada nilai Negelkerkel R Square berikut ini: 
Tabel 7

Cox \& Snell $R$ Square dan Negelkerke $R$ Square

\begin{tabular}{cccc}
\hline Step & $\begin{array}{c}-2 \text { Log } \\
\text { likelihood }\end{array}$ & $\begin{array}{c}\text { Cox \& Snell R } \\
\text { Square }\end{array}$ & $\begin{array}{c}\text { Nagelkerke R } \\
\text { Square }\end{array}$ \\
\hline 1 & $18.411^{\text {a }}$ & .578 & .803 \\
\hline \multicolumn{4}{c}{ Sumber: Output SPSS, data diolah 2020 }
\end{tabular}

Berdasarkan tabel 7 di atas dapat dilihat bahwa nilai Cox \& Snell R Square sebesar 0,578 hal ini berarti variabel yang terdapat pada model logit ini mampu menjelaskan sebuah perusahaan mengalami financial distress atau tidak sebesar 57,8\%, sedangkan koefisien determinasi yang diambil dari nilai Negelkerkel R Square adalah sebesar 0,803. Hasil analisis koefisien determinasi ini menjelaskan bahwa variabilitas variabel dependen yang dapat dijelaskan oleh variabel independen adalah sebesar 80,3\% dan sisanya sebesar 19,7\% dijelaskan oleh variabilitas variabel-variabel lain di luar model penelitian yang digunakan saat ini.

\section{Hasil Uji Hipotesis}

Variabel terikat dari penelitian ini memiliki 2 kategori (dichotomus) yaitu financial distress dan menggunakan model regresi logistik. Regresi logistik dalam penelitian ini digunakan untuk menguji pengaruh likuiditas, profitabilitas, leverage, dan arus kas operasi terhadap financial distress. Nilai p-value (probability value) yang digunakan untuk menguji signifikani koefisien dari setiap variabel bebas adalah 5\% (0.05), yang berarti variabel-variabel independen berpengaruh signifikan secara parsial terhadap variabel dependennya jika nilai probabilitas $<0.05$, namun sebaliknya jika probabilitas $>0.05$ maka tidak berpengaruh parsial terhadap variabel dependennya.

Tabel 8

Hasil Uji Hipotesis

\begin{tabular}{llcccccc}
\hline & & B & S.E. & Wald & Df & Sig. & $\operatorname{Exp}(\mathrm{B})$ \\
\hline Step 1 & CR & 3.267 & 1.591 & 4.219 & 1 & .040 & 26.240 \\
& ROA & -77.956 & 30.812 & 6.401 & 1 & .011 & .000 \\
& DR & 31.026 & 15.004 & 4.276 & 1 & .039 & 2.981 \\
& Arus Kas Operasi & .222 & .278 & .640 & 1 & .424 & 1.249 \\
& Constant & -20.180 & 9.842 & 4.204 & 1 & .040 & .000 \\
\hline
\end{tabular}

Sumber: Output SPSS, data diolah 2020

Berdasarkan tabel 8 di atas menunjukkan hasil uji hipotesis dari masing-masing variabel sebagai berikut:

1. Uji Hipotesis Pertama

Hasil ujihipotesis yang diperlihatkan pada tabel 8 di mana current ratio memiliki nilai koefisien regresi yang disimbolkan dengan $(\beta)$ sebesar 3,267 dengan signifikansi sebesar 0,040. Tingkat signifikan yang digunakan adalah sebesar $5 \%$ atau 0,05 . Hasil dari uji hipotesis ini adalah bahwa hipotesis pertama diterima karena tingkat signifikan dari current ratio lebih kecil dari tingkat signifikan yang telah ditetapkan $(0,040<0,05)$. Sehingga pada penelitian ini variabel rasio likuiditas yang diproyeksikan dengan current ratio dinyatakan berpengaruh positif dan signifikan terhadap kondisi financial distress perusahaan.

2. Uji Hipotesis Kedua

Berdasarkan hasil uji hipotesis yang diperlihatkan pada tabel 4.8 di mana return on asset memiliki nilai koefisien regresi yang disimbolkan dengan $(\beta)$ sebesar -77,956 dengan signifikansi sebesar 0,011. Tingkat signifikan yang digunakan adalah sebesar 5\% atau 0,05. Hasil dari uji hipotesis ini adalah bahwa hipotesis kedua diterima karena tingkat signifikan dari retur on asset lebih kecil dari tingkat signifikan yang telah ditetapkan $(0,011<0,05)$. Sehingga 
pada penelitian ini variabel rasio profitabilitas yang diproyeksikan dengan return on asset dinyatakan berpengaruh negatif dan signifikan terhadap kondisi financial distress perusahaan.

3. Uji Hipotesis Ketiga

Berdasarkan hasil uji hipotesis yang diperlihatkan pada tabel 8 di mana debt ratio memiliki nilai koefisien regresi yang disimbolkan dengan ( $\beta$ ) sebesar 31,026 dengan signifikansi sebesar 0,039 . Tingkat signifikan yang digunakan adalah sebesar $5 \%$ atau 0,05 . Hasil dari uji hipotesis adalah bahwa hipotesis ketiga diterima karena tingkat signifikan dari debt ratio lebih kecil dari tingkat signifikan yang telah ditetapkan $(0,039<0,05)$. Sehingga pada penelitian ini variabel rasio leverage yang diproyesikan dengan debt ratio dinyatakan berpengaruh positif dan signifikan terhadap kondisi financial distress perusahaan.

4. Uji Hipotesis Keempat

Berdasarkan hasil uji hipotesis yang diperlihatkan pada tabel 8 di mana arus kas operasi memiliki nilai koefisien regresi yang disimbolkan dengan $(\beta)$ sebesar 0,222 dengan signifikansi sebesar 0,424 . Tingkat signifikan yang digunakan adalah sebesar $5 \%$ atau 0,05 . Hasil dari uji hipotesis ini adalah bahwa hipotesis keempat ditolak karena tingkat signifikan dari arus kas operasi lebih besar dari tingkat signifikan yang telah ditetapkan $(0,424>0,05)$. Sehingga, pada penelitian ini variabel arus kas operasi dinyatakan tidak berpengaruh terhadap kondisi financial distress perusahaan.

\section{PEMBAHASAN}

Berdasarkan hasil penelitian yang didapatkan melalui berbagai pengujian diatas, dapat diinterpretasikan bahwa pengaruh variabel independen dan dependen adalah sebagai berikut:

1. Pengaruh Rasio Likuiditas Terhadap Kondisi Financial Distress Peusahaan Manufaktur Sub Sektor Food and Beverage yang Terdaftar di Bursa Efek Indonesia (2014-2018)

Rasio Likuiditas yang diproyeksikan dengan curent ratio mempunyai nilai $\beta$ 3,267 dengan signifikansi (sig) $0,040<\alpha=0,05$, sehingga dapat disimpulkan bahwa rasio likuiditas berpengaruh positif dan signifikan terhadap financial distress perusahaan manufaktur sub sektor food and beverage yang terdaftar di BEI tahun 2014-2018. Maka hipotesis pertama (H1) diterima, hasil penelitian ini mendukung hasil penelitian yang dilakukan oleh Mayang Murni (2018), dan Denny Liana (2014) yang menyatakan bahwa rasio likuiditas (current ratio) berpengaruh terhadap kondisi financial distress perusahaan.

Kemampuan perusahaan membayar utang lancar dengan aset lancar yang dimiliki merupakan penilaian likuiditas. Hasil penelitian yang menunjukkan bahwa likuiditas berpengaruh positif dan signifikan terhadap financial distress, Hal ini menandakan bahwa semakin tinggi nilai likuiditas maka semakin besar tingkat financial distress. Hal ini dikarenakan bahwa pada sampel perusahaan memiliki aset lancar yang tidak diperlukan dan tidak dapat menghasilkan pendapatan, contohnya piutang dagang yang mungkin pada akhirnya tidak tertagih. Dengan piutang dagang yang tidak tertagih tersebut, perusahaan tidak mampu membayar kewajibannya dengan menggunakan aset lancar yang dimilikinya sehingga mempengaruhi financial distress.

2. Pengaruh Rasio Profitabilitas Terhadap Kondisi Financial Distress Perusahaan Manufaktur Sub Sektor Food And Beverage yang Terdaftar di Bursa Efek Indonesia (2014-2018)

Rasio profitabilitas yang diproyeksikan dengan return on asset mempunyai nilai $\beta$ 77,956 dengan signifikansi sebesar $0,011<\alpha=0,05$, sehingga dapat disimpulkan bahwa rasio profitabilitas berpengaruh negatif dan signifikan terhadap kondisi financial distress perusahaan manufatur sub sektor food and beverage yang terdaftar BEI tahun 2014-2018. Maka hipotesis kedua (H2) diterima, hasil penelitian ini mendukung hasil penelitian yang dilakukan oleh Orina Andre dan Salma Taqwa (2014), Deny Liana (2014), Imam Mas'ud dan Reva Maymi (2012), dan Ketut Sudharma Nurcahyono (2014) yang menyatakan bahwa rasio profitabilitas berpengaruh terhadap financial distress. 
Penurunan profitabilitas menyebabkan kondisi perusahaan mengalami financial distress. Semakin tinggi profitabilitas maka semakin kecil kemungkinan perusahaan mengalami fianancial distress. Hal ini dikarenakan kemampuan memperoleh laba perusahaan yang semakin tinggi akan mempengaruhi kondisi keuangan yang baik, sehingga tidak akan terjadi financial distress. Tetapi bagi perusahaan yang memiliki profitabilitas rendah, tidak memiliki kekuatan ekonomi yang akan mendorong perusahaan mengalami financial distress. Berarti profitabilitas dapat memprediksi financial distress perusahaan.

3. Pengaruh Rasio Leverage Terhadap Kondisi Financial Distress Perusahaan Manufaktur Sub Sektor Food and Beverage yang Terdaftar di Bursa efek Indonesia (2014-2018)

Rasio leverage yang diproyeksikan dengan debt ratio mempunyai nilai $\beta$ 31,026 dengan signifikansi sebesar $0,039<\alpha=0,05$, sehingga dapat disimpulkan bahwa rasio leverage berpengaruh positif dan signifikan terhadap kondisi financial distress perusahaan manufaktur sub sektor food and beverage yang terdaftar di BEI tahun 2014-2018. Maka hipotesis ketiga (H3) diterima, hasil penelitian ini mendukung hasil penelitian yang dilakuan oleh Orina Andre dan Salma Taqwa (2014), Evanny Indri Hapsari (2012), dan Ketut Sudharma Nurcahyono (2014) yang menyatakan bahwa rasio leverage berpengaruh terahadap kondisi financial distress perusahaan.

Komposisi keuangan perusahaan yang memiliki hutang lebih besar daripada asetnya beresiko mengalami kesulitan pembiayaan. Hal ini dikarenakan hutang merupakan beban tetap perusahaan yang akan bertambah karena adanya bunga. Rasio utang memberikan gambaran mengenai tingkat resiko utang perusahaan, semakin tinggi debt ratio akan semakin sulit perusahaan membayar utang-utangnya dan menyebabkan tingkat financial distress yang semaik besar.

4. Pengaruh Arus Kas Operasi Terhadap Kondisi Financial Distress Perusahaan Manufaktur Sub Sektor Food and Beverage yang Terdaftar Di Bursa Efek Indonesia (2014-2018)

Arus Kas Operasi mempunyai nilai $\beta 0,222$ dengan signifikansi sebesar 0,424 $>\alpha=$ 0,05 , sehingga dapat disimpulkan bahwa arus kas operasi tidak berpengaruh terhadap kondisi financial distress perusahaan manufaktur sub sektor food and beverage yang terdaftar di BEI tahun 2014-2018. Maka hipotesis keempat (H4) ditolak. Hasil penelitian ini tidak konsisten dengan penelitian yang dilakukan oleh Imam Mas'ud dan Reva Maymi Srengga pada tahun 2012, yang membuktikan bahwa arus kas operasi berpengaruh terhadap kondisi financial distress perusahaan. Hal seperti ini dapat disebabkan oleh aktivitas arus kas lainnya. Perusahaan yang memiliki arus kas operasi yang positif namun memiliki arus kas investasi dan pendanaan yang negatif ini pada akhirnya menyebabkan kesulitan keuangan bagi perusahaan karena perusahaan tidak memiliki dana untuk membiayai kegiatan operasional perusahaan sehariharinya.

\section{KESIMPULAN}

Berdasarkan hasil analisis dan pembahasan yang telah dikemukakan pada bab-bab sebelumnya, maka penelitian ini dapat diambil kesimpulan sebagai berikut:

1. Rasio Likuiditas yang diproyeksikan dengan Current Ratio (CR) yang mempunyai nilai $\beta 3,267$ dengan signifikansi (sig) $0,040<\alpha=0,05$, dinyatakan bahwa berpengaruh positif dan signifikan terhadap financial distress, $\mathrm{H} 1$ diterima.

2. Rasio Profitabilitas yang diproyeksikan dengan Return On Asset (ROA) memiliki nilai $\beta-77,956$ dengan signifiansi sebesar $0,011<\alpha=0,05$, dinyatakan bahwa berpengaruh negatif dan signifikan terhadap financial distress, $\mathrm{H} 2$ diterima.

3. Rasio Leverage yang diproyeksikan dengan Debt Ratio (DR) memiliki nilai $\beta$ 31,026 dengan signifikansi sebesar $0,39<\alpha=0,05$, dinyatakan berpengaruh positif dan signifikan terhadap financial distress, $\mathrm{H} 3$ diterima. 
4. Arus Kas Operasi yang memiliki nilai $\beta 0,222$ dengan signifikansi sebesar $0,424>\alpha=0,05$, dinyatakan tidak berpengaruh terhadap financial distress, $\mathrm{H} 4$ ditolak.

5. Hasil dari analisis koefisien determinasi dengan nilai Negelkerke R Square sebesar 0,803. Artinya, variabel independen yang digunakan dalam penelitian ini mampu menjelaskan variabelitas variabel dependen sebesar 80,3\% sedangkan sisanya sebesar 19,7\% dijelaskan oleh variabel-variabel lain di luar penelitian.

\section{SARAN}

Berdasarkan hasil penelitian mengenai variabel-variabel yang telah diteliti oleh peneliti, maka peneliti mengemukakan saran dengan harapan dapat bermanfaat, antara lain sebagai berikut:

1. Bagi Perusahaan

Pihak manajemen mempersiapkan tindakan pencegahan jika perusahaan mengalami kondisi financial distress. Sehingga ketika perusahaan terindikasi financial distess, maka majamen perusahaan telah memiliki solusi untuk mengatasinya.

2. Bagi Investor

Pihak investor, agar lebih mempertimbangkan rasio keuangan terutama rasio profitabilitas dan rasio leverage dalam rangka pengambilan keputusan untuk berinvestasi.

3. Bagi Peneliti Selanjutnya

Untuk penelitian selanjutnya, diharapkan memperpanjang tahun pengamatan sehingga ditribusi data lebih baik. Dan sampel yang digunakan bukan hanya perusahaan manufaktur saja. Penambahan variabel penelitian dnegan menggunakan kategori selain rasio keuangan, faktor lain yang mempengaruhi financial distress, seperti Good Corporate Governance, Ukuran perusahaan, Corporate Social Responsibility (CSR).

\section{DAFTAR PUSTAKA}

Amir Saleh \& Bambang Sudiyatno (2013). Pengaruh Rasio Keuangan Untuk Memprediksi Probabilitas Kebangkrutan Pada Perusahaan Manufaktur yang Terdaftar Di Bursa Efek Indonesia. Jurnal Dinamika Akuntansi, Keuangan, dan Perbankan, Vol. 2, No. 1.

Chalendra Prasetya Agusti (2013). Analisis Faktor yang Mempengaruhi Kemungkinan Terjadinya Financial Distress. Semarang: Fakultas Ekonomika dan Bisnis Universitas Diponegoro.

Daftar Perusahaan Delisting. (https://www.belajarcuan.com/2019/01/daftar-saham-delistingtahun-2018.html, diakses 01 Agustus 2020).

Deny Liana (2014). Analisis Rasio Keuangan Untuk Memprediksi Kondisi Financial Distress Perusahaan Manufaktur. Jurnal Studi Manajemen dan Bisnis, Vol. 1, No. 2.

Emrinaldi Nur DP (2007). Analisis Pengaruh Tata Kelola Perusahaan (corporate governance) Terhadap Kesulitan Keuangan Perusahaan (financial distress): Suatu Kajian Empiris. Jurnal Bisnis dan Akuntansi, Vol. 9, No. 1, Hal: 99 - 108.

Evanny Indri Hapsari (2012). Kekuatan Rasio Keuangan Dalam Memprediksi Kondisi Financial Distress Perusahaan Manufaktur Di BEI. Jurnal Dinamika Manajemen, Vol. 3, No. 2, Hal: $101-109$.

Fahmi Irham (2013). Analisis Laporan Keuangan. Bandung: Alfabeta.

Gamayuni Rindu Rika (2006). Rasio Keuangan Sebagai Prediktor Kegagalan Perusahaan di Indonesia. Jurnal Bisnis dan Manajemen, Vol. 3, No. 1.

Imam Mas'ud \& Reva Maymi Srengga (2012). Analisis Rasio Keuangan Untuk Memprediksi Kondisi Financial Distress Perusahaan Manufaktur Yang Terdaftar Di Bursa Efek Indonesia Tahun 2006-2010. Jurnal Akuntansi Universitas Jember, Vol. 10, No. 2.

Imam Ghozali (2009). Teori Konsep dan Aplikasi dengan SPSS 17. Semarang: Universitas Diponegoro.

Juyneo Pratama (2016). Prediksi Financial Distress Pada Perusahaan Manufaktur Di Bursa Efek Indonesia.Yogyakarta: Fakultas Ekonomi Universitas Negeri Yogyakarta. 
Kapitalisasi Pasar. (https://www.sahamok.com/emiten/kapitalisasi -pasar/, diakses 05 Mei 2020).

Ketut Sudharma Nurcahyono (2014). Analisis Rasio Keuangan Untuk Memprediksi Kondisi Financial Distress. Jurnal Analisis Manajemen, Vol. 3, No. 1.

Laporan Keuangan dan Tahunan. (https://www.idx.co.id/perusahaantercatat/laporankeuangan-dan-tahunan/, diakses 05 Mei 2020).

Luciana Spica Almilia (2003). Analisis Rasio Keuangan Untuk Memprediksi Kondisi Financial Distress Perusahaan Manufaktur yang Terdaftar di Bursa Efek Jakarta. Jurnal Akuntansi dan Auditing Indonesia, Vol. 7, No. 2.

Mayang Murni (2018). Analisis Faktor-Faktor yang Mempengaruhi Tingkat Financial Distress Pada Perusahaan Manufaktur yang Terdaftar Di BEI Tahun 2010-2014. Jurnal Akuntansi dan Bisnis, Vol. 4, No. 1, Hal: 73 - 83.

Ni Luh Made Ayu Widhiari (2015). Pengaruh Rasio Likuiditas, Leverage, Operating Capacity, Dan Sales Growth Terhadap Financial Distress.Jurnal Akuntansi Universitas Udayana, Vol. 11, No. 2, Hal: 456 - 469.

Orina Andre \& Salma Taqwa (2014). Pengaruh Profitabilitas, Likuiditas, dan Leverage Dalam Memprediksi Financial Distress. Jurnal Akuntansi Universitas Negeri Padang, Vol. 2, No. 1.

Riza Milatul Khoiriyah (2018). Analisis Variabel Penjelas Terhadap Kondisi Financial Distress Pada Perusahaan Non-Keuangan yang Terdaftar Di Bursa Efek Indonesia. Yogyakarta: Program Studi Manajemen Fakultas Ekonomi Universitas Yogyakarta.

Rudianto (2013). Akuntansi Manajemen. Jakarta: Erlangga.

Rr Iramani (2007). Analisis Struktur Kepemilikan dan Rasio Relatif Industri Sebagai Prediktor dalam Model Kesulitan Keuangan. Jurnal Bisnis dan Manajemen, Vol. 1, No. 1.

Sejarah dan Profil Singkat Perusahaan Makanan dan Minuman. (https://www.britama.com/, diakses 02 Juni 2020).

Sugiyono (2014). Metode Penelitian Pendidikan Pendekatan Kuantitatif, Kualitatif dan R\&D. Bandung: Eidos.

Syafrida Hani (2015). Engineering Analysis Of The Financial Distress Statements. Terrain: UMSU PRESS.

Wardhani, R. (2006). Mekanisme corporate governance dalam perusahaan yang mengalami permasalahan keuangan (financially distressed firms). Simposium Nasional Akuntansi 9 Padang, 1-26. 